\title{
PKM Pendampingan Pengurus dalam Membentuk Santri Berkarakter Jujur di Asrama MI Nurul Mun'im Pondok Pesantren Nurul Jadid
}

Moh Rofiqi ${ }^{1 *}$, Ahmad Zubaidi ${ }^{2}$, Imam Subki ${ }^{3}$, Lukman Sholeh ${ }^{4}$

Universitas Nurul Jadid, Paiton ${ }^{1234}$

\begin{tabular}{lll}
\multicolumn{1}{c}{ Submission: 28/12/2021 Received: 31/12/2021 } & Published: 31/12/2021 \\
\hline Katakunci: & Abstrak. Pendampingan ini bertujuan untuk membina para pengurus \\
Pendampingan & yang ada di Wilayah Nurus Shobah Pondok Pesantren Nurul Jadid \\
Pengurus, & agar mampu menanamkan nilai-nilai pendidikan karakter, utamanya \\
Pendidikan & pada sikap kejujuran di dalam kesehariannya, mengingat tugas \\
Karakter, dan & pengurus adalah mendampingi santri (anak) mulai sejak mereka \\
Anak. & bangun untuk melaksanakan aktivitas di pagi hari hingga menjelang \\
& tidur kembali. Adapun metode yang digunakan selama proses \\
& pembinaan ini adalah metode ceramah dengan pendekatan \\
& partisipatoris. Hasil dari pengabdian ini bahwa karakter anak dapat \\
& dipahami melalui beberapa hal antara lain; gambar yang ia buat, \\
& gerakan tubuh maupun tangan, serta perubahan pada ekspresi wajah \\
& mereka. Selain itu, untuk mewujudkan kejujuran pada anak, penting \\
& bagi pengurus untuk menyakinkan pada mereka bahwa kejujuran \\
& akan mendatangkan keuntungan pada mereka, melahirkan \\
& kepercayaan dari orang lain, serta perlu melatih mereka untuk \\
& bertutur kata yang benar dan tidak menjadikan kebohongan sebagai \\
& kebiasaan karena akan sangat merugikan orang lain.
\end{tabular}

\section{Pendahuluan}

Sebagai negara rechtstaat, penyelenggaraan negara ini harus didasarkan pada hukum positif yang berlaku di Indonesia, tidak hanya politik, hukum, lingkungan, dan budaya, tetapi juga termasuk di dalamnya adalah pendidikan. Hal ini untuk memastikan negara ini berjalan sesuai dengan rel atau koridor yang telah disepakati dan ditetapkan oleh pemerintah berdasarkan aspirasi publik. Dalam hal pendidikan, Pasal 3 Undang-Undang Republik Indonesia No 20 Tahun 2003 tentang Sistem Pendidikan Nasional menyebutkan bahwa

\footnotetext{
"Pendidikan nasional berfungsi mengembangkan kemampuan dan membentuk watak serta peradaban bangsa yang bermartabat dalam rangka mencerdaskan kehidupan bangsa, bertujuan untuk berkembangnya potensi peserta didik agar menjadi manusia yang beriman dan bertakwa kepada Tuhan Yang Maha Esa, berakhlak mulia, sehat, berilmu, cakap, kreatif, mandiri, dan menjadi warga negara yang demokratis serta bertanggung jawab".
} 
Berdasarkan ketentuan dalam rumusan di atas, untuk mewujudkan peserta didik yang bermartabat, cerdas, berbudi luhur, sehat secara jasmani dan rohani, serta memiliki rasa tanggung jawab yang tinggi, tidak bisa dilepaskan dari peran suatu lembaga pendidikan. Hal ini menunjukkan bahwa pendidikan memiliki tanggung jawab utama dalam menanamkan karakter kepada peserta didik. Sebagai penanggungjawab utama, maka pemerintah melalui lembaga-lembaga terkait sangat menekankan akan pentingnya pendidikan karakter di sekolah, terutama pendidikan moral (kejujuran) (Amin, 2017).

Zubaedi menyatakan bahwa pendidikan karakter dipahami sebagai upaya penanaman kecerdasan dalam berpikir, penghayatan dalam bentuk sikap, dan pengamalan dalam bentuk prilaku yang sesuai dengan nilai-nilai luhur yang menjadi jati dirinya, diwujudkan dengan interaksi dengan Tuhannya, diri sendiri, antar sesama, dan lingkungannya (Zubaedi, 2015). Terkait dengan apa saja muatan dari pendidikan karakter tersebut, Kun Setyaning Astuti sebagaimana dikutip oleh Darmiyati Zuchdi bahwa terdapat 16 nilai-nilai dasar yang. Menjadi target pendidikan karakter, yaitu taat beribadah, jujur, bertanggung jawab, disiplin, memiliki etos kerja, mandiri, sinergis, kritis, kreatif dan inovatif, visioner, kasih sayang dan peduli, ikhlas, adil, sederhana, nasionalisme dan internasionalisme (Zuchdi, 2011).

Salah satu topik penting dalam pendidikan karakter adalah penanaman nilai-nilai kejujuran. Kejujuran sampai detik ini masih menjadi perbincangan masyarakat Indonesia, karena berbagai problem bangsa, seperti korupsi dan berbagai kejahatan lainnya berawal dari hilangnya sikap jujur pada diri orang tersebut. Emosda mengemukakan bahwa tujuan utama sebuah pendidikan adalah membentuk kejujuran, sebab kejujuran adalah modal dasar dalam kehidupan bersama dan kunci menuju keberhasilan (Emosda, 2011). Melalui kejujuran kita dapat mempelajari, memahami, dan mengerti tentang keseimbangankeharmonisan. Jujur terhadap peran pribadi, jujur terhadap hak dan tanggung jawab, jujur terhadap tatanan yang ada, jujur dalam berfikir, bersikap, dan bertindak. Kecurangan adalah sebuah bentuk ketidakjujuran yang acap kali terjadi dalam kehidupan. Bila kejujuran sudah hilang, maka kekacauan dan ketidakharmonisan akan menguasai situasi dan yang ada hanya rekayasa dan manipulasi, penyerobotan hak, penindasan, dan sebagainya. 
Sementara grand design Pendidikan Karakter diungkapkan nilai-nilai yang akan dikembangkan dalam budaya satuan pendidikan formal dan nonformal, dengan penjelasannya adalah sebagai berikut (Suriawati, 2016):

1. Jujur, menyatakan apa adanya, terbuka, konsisten antara apa yang dikatakan dan dilakukan, berani karena benar, dapat dipercaya dan tidak curang.

2. Tanggung jawab, melakukan tugas sepenuh hati, bekerja dengan etos kerja yang tinggi, berusaha keras untuk mencapai prestasi terbaik, mampu mengontrol diri dan mengatasi stres, berdisiplin diri, akuntabel terhadap pilihan dan keputusan yang diambil.

3. Cerdas, berpikir secara cermat dan tepat, bertindak dengan penuh perhitungan, rasa ingin tahu yang tingi, berkomunikasi efektif dan empatik, bergaul secara santun, menjunjung kebenaran dan kebajikan, mencintai Tuhan dan lingkungan.

4. Sehat dan Bersih, menghargai ketertiban, keteraturan, kedisiplinan, terampil, menjaga diri dan lingkungan, menerapkan pola hidup seimbang.

5. Peduli, memperlakukan orang lain dengan sopan, bertindak santun, toleran terhadap perbedaan, tidak suka menyakiti orang lain, mau mendengar orang lain, mau berbagi, tidak merendahkan orang lain, tidak mengambil keuntungan dari orang lain, mampu bekerja sama, mau terlibat dalam kegiatan masyarakat, menyayangi manusia dan makhluk lain, setia, cinta damai dalam menghadapi persoalan.

6. Kreatif, mampu menyelesaikan masalah secara inovatif, luwes, kritis, berani mengambil keputusan dengan cepat dan tepat, menampilkan sesuatu secara luar biasa (unik), memiliki ide baru, ingin terus berubah, dapat membaca situasi dan memanfaatkan peluang baru.

7. Gotong royong, mau bekerja sama dengan baik, berprinsip bahwa tujuan akan lebih mudah dan cepat tercapai jika dikerjakan bersamasama, tidak memperhitungkan tenaga untuk saling berbagi dengan sesama, mau mengembangkan potensi diri untuk dipakai saling berbagi agar mendapatkan hasil yang terbaik, tidak egois. 
Kejujuran adalah sikap atau perilaku untuk bertindak sesungguhnya dan apa adanya, tidak berbohong, tidak dibuat-buat, tidak tambah dan tidak dikurangi,dan tidak menyembunyikan kejujuran (Lena et al., 2020). Jadi karakter jujur adalah karakter yang tercemin dalam perkataan, perbuatan, tulisan dan tindakan yang mencerminkan keadaan sebenarnya.

Pendidikan karakter atau akhlak merupakan aspek pendidikan tersulit dalam dunia pendidikan secara umum. Hal itu karena pendidikan akhlak merupakan bagian dari pendidikan jiwa yang tidak dapat langsung dilihat oleh kasat mata seperti halnya pendidikan fisik. Walaupun pendidikan karakter merupakan pendidikan yang sangat sulit, tetapi pembentukan karakter merupakan hal yang sangat urgen dan tidak dapat diabaikan, karena karakter berkaitan erat dengan kebahagiaan dan kesuksesan seseorang.

Sekolah diharuskan untuk mengembangkan dan membantu karakter siswa sesuai dengan moral, nilai dan norma yang ada di masyarakat (Sawaludin et al., 2019). Harapannya adalah siswa mempunyai perilaku budi pekerti luhur, dan hal ini memang sangat sulit bagi lembaga pendidikan, seperti sekolah maupun pesantren untuk melaksanakan pendidikan dan pengajaran kepada peserta didik. Salah satu dampak yang ditimbulkan dari program pendidikan karakter di lingkungan pendidikan adalah terciptanya generasi bangsa yang amanah, terwujudnya kehidupan masyarakat yang nyaman dan tentram, terbina hubungan yang harmonis antar sesama anak bangsa, dan terjaminnya rasa keadilan serta hak asasi manusia (Arrahim, 2016).

Salah satu lembaga pendidikan dan pesantren yang memiliki beragam tingkat pendidikan mulai dari Pendidikan Anak Usia Dini hingga Perguruan Tinggi adalah Pondok Pesantren Nurul Jadid yang terletak di Desa Karanganyar, Kecamatan Paiton, Kabupaten Probolinggo. Pesantren yang didirikan oleh KH. Zaini Mun'im ini memiliki asrama khusus untuk anak-anak dengan jenjang pendidikan Madrasah Ibtidaiyah Nurul Mun'im yakni Wilayah Nurus Shobah. Hal yang menarik dari wilayah ini adalah bahwa Peserta didik atau santri yang bermukim di Wilayah Nurus Shobah ini berasal dari berbagai daerah, baik dari dalam Kabupaten Probolinggo itu sendiri maupun dari luar Kabupaten Probolinggo. Selain itu, karena berasal dari tempat yang berbeda, tentu masing-masing santri (anak) memiliki budaya dan karakter yang berbeda antara anak yang satu dengan anak yang lainnya, baik dari segi 
kebiasaan, bahasa (cara berkomukasi), maupun sikap atau perilaku yang baik maupun yang buruk.

Pada aspek ini, sangat penting peran dari setiap pengurus yang ada di wilayah Nurus Shobah tersebut untuk membangun suasana wilayah yang rukun, nyaman, dan harmonis demi tercapainya tujuan dan cita-cita bersama, yakni menjadi santri yang berkarakter dan berakhlak mulia, serta berilmu yang nafi' (bermanfaat). Pengabdian ataupun pendampingan ini selain dilatarbelakangi oleh kondisi sebagaimana telah dipaparkan di atas, juga tidak lepas dari kegelisahan kami selaku pengabdi yang seringkali mendengar kejadian atau peristiwa kehilangan barang salah satu santri (anak), adanya ketidakcocokan di antara mereka dengan salah satu temannya sehingga melahirkan konflik, serta ada sebagian santri (anak) yang tidak betah untuk tinggal di asrama tersebut karena perlakuan kurang menyenangkan dari teman-temannya. Untuk menyelesaikan berbagai persoalan yang ada di wilayah Nurus Shobah tersebut, kami berinisiatif mengubah pola perilaku di atas dengan langkah awal yakni melakukan pembinaan kepada segenap pengurus yang ada di wilayah tersebut agar bisa memahami karakter dan mengarahkan masing-masing anak yang diamanahkan kepada mereka terhadap problematika yang dialami si anak tersebut. Penanaman karakter ini bisa ditanamkan melalui kegiatan-kegiatan seharian yang didsampingi oleh pengurus pada asrama tersebut.

Dalam kegiatan pengabdian ini lebih menfokuskan pada pendamping kepada pengurus Asrama MI Nurul Mun'im untuk melakukan update pengetahuan tentang pengelolaan anak di bawah usia tiga belas tahun, dalam hal ini narasumber memberikan tutorial dan pendampingan serta memberikan contoh penamanan karakter kepada anak yang ada di wilayah tersebut. Di dalam wilayah tersebut terdapat 16 santri (anak) yang menetap dan 6 pengurus yang sekaligus menjadi ayah/pengasuh untuk mereka. Adapun tema pengabdian kepada masyarakat ini adalah pendampingan pengurus dalam membentuk santri berkarakter jujur di Asrama MI Nurul Mun'im Pondok Pesantren Nurul Jadid. 


\section{Metode}

Metode pendampingan yang digunakan dalam kegiatan pengabdian ini adalah metode ceramah dengan pendekatan partisipasitoris, di mana pendamping menyampaikan terlebih dahulu secara teoritis tentang konsep dan pendidikan karakter pada anak, serta memahami psikologi anak, kemudian terlibat langsung di lapangan untuk melakukan manajemen dan penyelesaian berbagai problematika anak di lapangan bersama-sama dengan pengurus di Wilayah Nurus Shobah. Adapun objek dampingan ini adalah semua pengurus yang bermukim di Wilayah Nurus Shobah yang berjumlah 6 orang yang secara khusus bertugas untuk mengayomi, mendidik, dan menjaga santri yang keseluruhannya masih mengeyam pendidikan di Madrasah Ibtidaiyah Nurul Mun'im. Program ini dimulai sejak tanggal 05 Juli sampai 05 September 2021, dengan melibatkan kolaborasi antara 1 dosen, 1 orang ahli psikologi anak, serta 8 mahasiswa yang memiliki tugas dan peran masing-masing.

Langkah awal yang dilakukan dalam pelaksanaan PkM ini adalah melakukan observasi awal dengan terjun dan study lapangan untuk mengetahui kebutuhan dan kondisi di lapangan. Yang secara rinci tahapan-tahapan dalam PkM ini diuraikan pada bagian berikut;

1. Kegiatan ini diawali dengan menjalin komunikasi dan menyusun perencanaan kegiatan dengan pengurus Asrama Nurus Shobah (Wilayah MI Nurul Mun'im) agar tujuan kegiatan ini dapat terwujud.

2. Agar pelaksanaan kegiatan ini berjalan dengan baik dan tepat sasaran, langkah selanjutnya adalah melakukan FGD kepada pengurus untuk update pengetahuan tentang penanaman karakter kejujuran. Selain dilibatkan dalam proses pelaksanaan penyuluhan dan pendampingan, mereka juga dilibatkan dalam penanaman karakter kejujuran.

3. Untuk mencapai kompetensi yang ingin dicapai dalam kegiatan ini, tahap selanjutnya adalah menyusun materi penyuluhan dan menentukan model pendampingan dalam mengimplementasikan materi-materi yang telah disusun sebelumnya.

4. Melakukan evaluasi terhadap semua target kegiatan PKM.

5. Tahap terakhir dalam kegiatan ini adalah penyusunan laporan kegiatan dan publikasi artikel yang diterbitkan dalam jurnal ilmiah. 


\section{Hasil dan Pembahasan}

Sebagaimana telah disebutkan pada bagian terdahulu bahwa secara teknis pembinaan ini meliputi 5 (lima) langkah utama, di mana masing-masing bagian saling terkait satu dengan yang lainnya. Langkah atau tahapan awal hingga tahap akhir akan diuraikan secara sistematis dan komprehensif pada bagian berikut;

\section{Tahap Pemetaan dan Identifikasi Masalah}

Kegiatan pengabdian ini merupakan salah satu program strategis yang dicanangkan oleh Universitas Nurul Jadid. Sebagaimana disampaikan oleh Rektor Universitas Nurul Jadid bahwa pendampingan harus berorientasi pada nilai kebermanfaatan kepada masyarakat. Tim melakukan proses pemetaan sekaligus mengidentifikasi berbagai masalah di lapangan pada tanggal $05 \mathrm{Juli}$ 2021. Sebelum pemetaan dilakukan, tim melakukan komunikasi awal dengan kepala Asrama Nurul Shobah. Komunikasi ini dimaksudkan untuk menyampaikan maksud dan tujuan dari kegiatan pengabdian kepada masyarakat ini. Direncanakan kegiatan pembinaan ini akan dilaksanakan secara pararel selama kurang lebih 4 minggu, tanpa menggangu aktifitas pengurus dan santri Nurus Shobah.

Selama proses pemetaan dan identifikasi masalah dilakukan, Tim berhasil menemukan beberapa persoalan atau masalah yang dihadapi para pengurus, antara lain bahwa faktor bawaan dari keluarga santri. Kedua kedisiplinan waktu kegiatan asrama, kedisiplinan menjadi penentu untuk membudayakan sifat jujur dalam setiap kegiatan. Ketiga minimnya peran orang tua, peran orang tua menjadi penting dalam membentuk karakter jujur pada anak. Keempat lemahnya suri tauladan dari para pengurus wilayah, idealnya pengurus harus menjadi suri tauladan yang baik dan jujur terhadap anak didik, mengingat mereka akan meniru apa yang mereka alami dan mereka lihat.

\section{Tahap Perencanaan Pembinaan}

Setelah proses pemetaan dan pengidentifikasian masalah selesai, maka Tim melakukan focus group discussion (FGD) guna menentukan tindak lanjut 
berikutnya, yakni merencanakan format kegiatan pembinaan. Hal ini dimulai dengan menentukan tema yang sesuai dengan kondisi di lapangan, waktu pelaksanaan kegiatan, hingga penanggungjawab kegiatan selama pembinaan berlangsung.

Pada tahap ini, Tim menyepakati tema penting kegiatan update pengetahuan pengurus tentang "Membudayakan Jujur dalam Keseharian Anak". Dalam kegiatan ini nantinya diharapkan kejujuran tidak hanya menjadi bagian penting pada diri anak, dan segenap pengurus, tetapi juga tercipta lingkungan yang mendukung terhadap pembentukan karakter jujur tersebut. Adapun beberapa materi yang akan disajikan dalam kegiatan pembinaan ini dan telah disepakati bersama dengan para pengurus antara lain sebagaimana berikut:

1. Memahami karakter dan psikologi anak;

2. Manajemen pendidikan karakter bagi anak

3. Manajemen konflik; mengatasi problematika pada anak

4. Implementasi pendidikan karakter pada anak

5. Simulasi perilaku jujur

Gambar 2: Rapat Koordinasi Tema Pengabdian

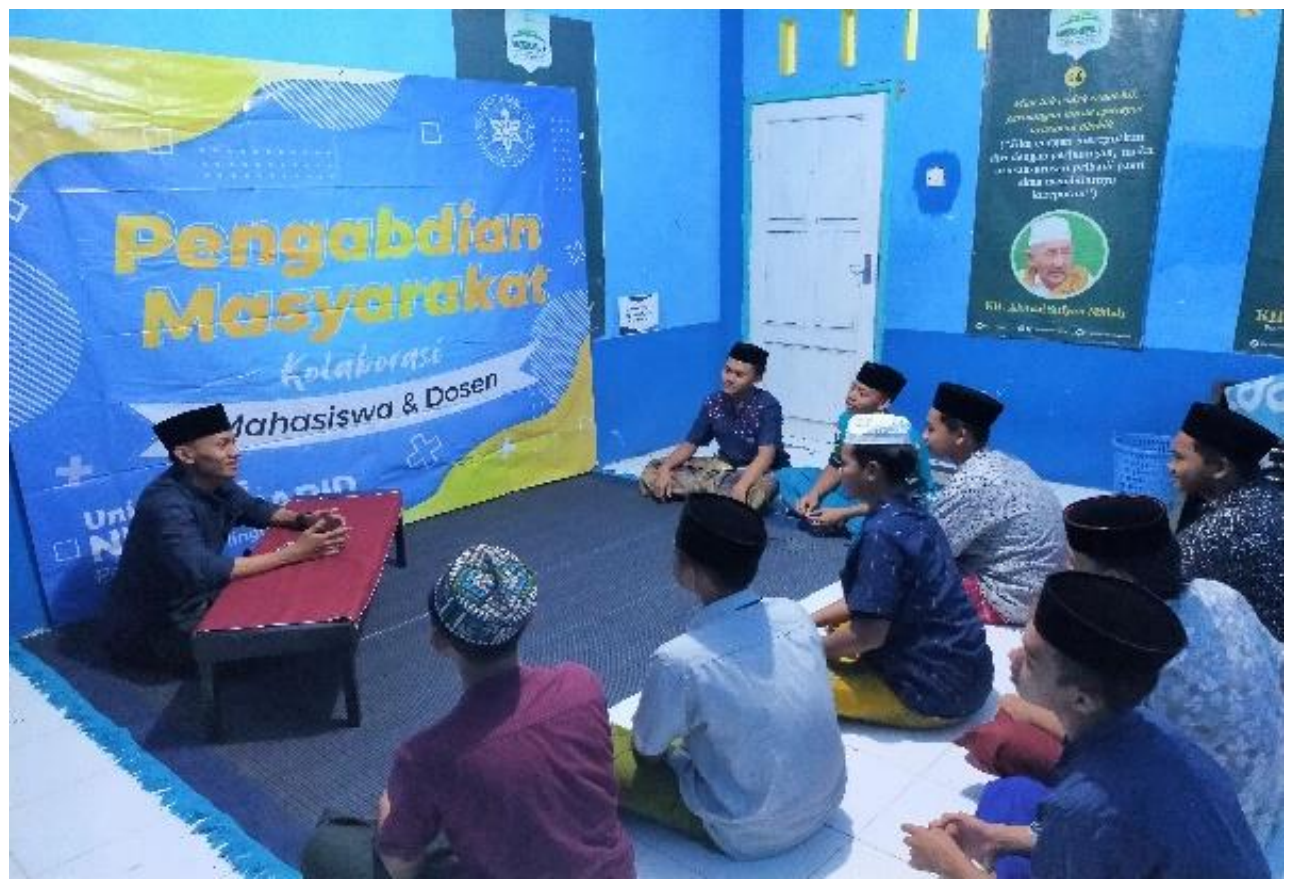




\section{Tahap Pelaksanaan Kegiatan}

Pada tahap ini, seluruh perencanaan yang telah disiapkan sebelumnya dari hasil koordinasi dengan pengurus Wilayah Nurus Shobah akan diimplementasikan kepada seluruh peserta binaan. Pertama melakukan inventalisir latar belakang keluarga, baik pendidikan, konsidisi ekonomi dan sosial karena itu menjadi faktor penentu dalam proses penanaman karakter anak. Setelah memiliki semua informasi tentang background pada tiap-tiap anak, maka hasilnya dikoordinasikan kembali dengan Tim Pengabdi untuk kemudian dilakukan klasifikasi terhadap masing-masing isu guna menemukan solusi penyelesaiannya, dan nanti hasilnya akan disampaikan secara langsung pada saat kegiatan pembinaan kepada pengurus berlangsung sesuai dengan materi yang telah ditentukan:

\begin{tabular}{|c|l|l|l|}
\hline NO & Materi & Waktu & Narasumber \\
\hline 1 & $\begin{array}{l}\text { Memahami karakter dan } \\
\text { psikologi anak }\end{array}$ & 10 Juli 2021 & Eka Diana, M.Pd \\
\hline 2 & $\begin{array}{l}\text { Manajemen pendidikan } \\
\text { karakter bagi anak }\end{array}$ & 20 Juli 2021 & Rofiqi, M.Pd \\
\hline 3 & $\begin{array}{l}\text { Manajemen konflik; mengatasi } \\
\text { problematika pada anak }\end{array}$ & 25 Juli 2021 & Rofiqi, M.Pd \\
\hline 4 & $\begin{array}{l}\text { Implementasi pendidikan } \\
\text { karakter pada anak }\end{array}$ & 30 Juli 2021 & Rofiqi, M.Pd \\
\hline 5 & $\begin{array}{l}\text { Simulasi perilaku jujur dan } \\
\text { penutup }\end{array}$ & $\begin{array}{l}\text { 05 September } \\
\text { 2021 }\end{array}$ & Tim PkM \\
\hline
\end{tabular}

Ibu Eka Diana, M.Pd sebagai narasumber pertama dengan tema "memahami karakter dan psikologi anak" menjelaskan berbagai hal secara komprehensif dan sangat menarik. Penjelasan beliau awali dengan uraian tentang Psikologi Bawah Sadar, yaitu ilmu pengetahuan yang menjelaskan tentang apa yang dipikirkan dan dirasakan seseorang, dapat dibaca melalui gerakan tubuh, tulisan tangan, fisionomi/bentuk wajah, dan intuisi. Menurut beliau, setiap orang dapat mengetahui kepribadian atau karakter seorang anak, bakatnya, minatnya, termasuk cara mengarahkannya hanya melalui gambar anak. Di dunia ini, anak adalah sosok manusia yang paling suka menggambar. Selain melalui gambar, bahasa tubuh pada diri anak dapat digunakan untuk memperoleh informasi tentang apa yang ada dalam pikiran 
seorang anak, mulai dari cara ia berdiri, menggerakkan tangan, hingga perubahan pada ekspresi wajahnya. Semua materi tersebut beliau urai satu persatu dan dijelaskan secara sistematis. Penjelasan beliau yang memukau membuat semua peserta sangat antusias menyimaknya. Pada sesi ini, terjadi dialog yang sangat dinamis, karena mereka belum pernah mengetahui ilmu pengetahuan baru yang dipaparkan sebelumnya.

Pada pertemuan kedua, dengan materi "manajemen pendidikan karakter bagi anak", Bpk. Rofiqi, M.Pd melanjutkan penjelasan yang disampaikan narasumber sebelumnya. Bahwa pendidikan karakter merupakan pendidikan budi pekerti yang meliputi 3 aspek penting, yakni aspek pengetahuan, aspek perasaan, dan aspek tindakan. Tanpa melibatkan ketiga aspek tersebut, pendidikan karakter tidak akan efektif. Jadi yang diperlukan dalam pendidikan karakter tidak cukup hanya dengan pengetahuan, lalu kemudian melakukan tindakan berdasarkan pengetahuan tersebut. Hal ini karena pendidikan karakter terkait dengan nilai dan norma. Oleh karena itu, harus juga melibatkan perasaan. Jadi pendidikan karakter harus dipahami sebagai upaya penanaman kecerdasan dalam berfikir, penghayatan dalam bentuk sikap, dan pengamalan dalam bentuk perilaku yang sesuai dengan nilai-nilai luhur yang menjadi jati dirinya.

Dilanjutkan dengan materi "manajemen konflik; mengatasi problematika pada anak" pada pertemuan ketiga, Bpk. Rofiqi, M.Pd lebih dalam lagi memaparkan bagaimana mengatasi berbagai problematika pada anak serta solusinya. Bagian ini beliau awali dengan penjelasan bahwa setiap orang pasti pernah mengalami konflik, termasuk anak sekalipun, mulai dari rebutan tempat, mainan, maupun makanan, tidak mau mengalah, hingga berantem antar sesama anak. Konflik tersebut dapat saja berbentuk ringan, sedang, hingga berat, tergantung bagaimana masing-masing menyikapi sejauh mana konflik tersebut harus diselesaikan. Konflik yang didiamkan selama berharihari yang terjadi pada anak, akan sangat mengganggu kesehatan mental pada si anak tersebut. Untuk itu, perlu diberikan solusi terbaik bagi anak. Dalam konflik muncul apa yang disebut dengan interaksi, yang ditandai dengan menekan pihak lain untuk mendapatkan keuntungan tertentu, baik dalam konflik skala kecil maupun besar. Dari sini sekilas, konflik selalu tampak sebagai hal yang negatif, padahal jika dimanajemen dengan baik konflik juga dapat bernilai positif. Dengan adanya konflik, seseorang dapat terpacu untuk 
berkembang menjadi insan yang lebih baik. Ketika seseorang berhasil menyelesaikan suatu konflik, misalnya dalam suatu hubungan (termasuk jalinan hubungan antar anak), maka hubungan diantara mereka akan menjadi semakin kuat. Dari paparan beliau yang sangat menarik, banyak dari peserta yang berdialog dengan pemateri hingga melewati batas waktu yang telah ditentukan.

Pada bagian/pertemuan keempat dengan tema untuk materi kali ini adalah "implementasi pendidikan karakter pada anak", Bpk. Rofiqi, M.Pd menyajikan materi dengan penuh semangat. Beliau mengantarkan peserta secara taktis dan teknis tentang penerapan pendidikan karakter pada anak sesuai dengan tujuan utamanya yakni membangun insan yang tangguh, berakhlak mulia, penuh dengan sikap toleransi, sehingga tercipta kehidupan yang nyaman, harmonis, dan tentram. Untuk mewujudkan anak berkarakter jujur dalam kehidupan sehari-hari, termasuk di sekolah, adalah dengan menyakini bahwa kejujuran adalah sikap yang dapat membangun kepercayaan dari orang lain, melatih diri untuk berkata benar dan sesuai dengan fakta yang dilihat, dirasakan, dan dialami sendiri, serta tidak menjadikan kebohongan sebagai bahan candaan dalam pergaulan dengan sesama, dan lain sebagainya.

Sebagai pemuncak dari kegiatan pengabdian ini, secara bersama-sama, baik Tim, narasumber, maupun pengurus, mengadakan simulasi perilaku jujur terhadap peserta didik, dengan melatih beberapa sikap jujur, antara lain tidak berbohong, tidak mencontek saat ujian, tidak membeda-bedakan teman berdasarkan asal-usul daerah, bahasa, dan lain sebagainya. Tidak hanya itu, pada sesi simulasi ini, pengurus diberi kesempatan untuk melatih diri menyikapi seorang anak yang berperan sebagai pembohong, pencontek, dan bersikap rasial terhadap temannya. Sesi ini berjalan cukup serius, namun juga banyak ditemukan beberapa kendala atau kesulitan dari pengurus dalam menghadapi dan memahami kondisi anak.

\section{Tahap Evaluasi}

Keberadaan pendampingan ini diapresiasi oleh seluruh pengurus Nurus Shobah, karena dinilai sangat bermanfaat bagi pengurus untuk menambah pengetahuan tentang mendidik dan menganyomi anak didik, mengingat dari 
seluruh pengurus mempunyai latar belakang yang sangat beragam dan belum pernah mengenyam pendidikan yang berbicara secara khusus dan intens tentang psikologi anak, sehingga diharapkan kegiatan-kegiatan semacam ini bisa terus dilakukan dalam mengembangan asrama Nurus Shobah ke depan guna menciptakan pelayanan dan pembinaan santri yang maksimal dan berkarakter.

Dari beberapa kegiatan yang telah dilaksanakan dalam pengabdian ini, ada beberapa kendala yang kami beserta Tim temukan, antara lain, masih ada sebagian kecil pengurus yang belum memahami secara utuh mengenai pendidikan karakter pada anak dan penerapannya, hal ini karena mereka sering datang terlambat dan bahkan absen untuk salah satu materi. Selain itu, ternyata di lapangan ada temuan tentang kondisi anak yang memiliki kondisi berbeda dengan anak pada umumnya, yang perlu diperlakukan dan disikapi juga secara berbeda. Materi ini tidak tercakup atau luput untuk disajikan dalam kegiatan pengabdian ini oleh Tim, sehingga perlu ada tindak lanjut secara khusus di kemudian hari.

\section{Kesimpulan}

Berdasarkan paparan di atas, dapat disimpulkan bahwa pendidikan karakter akan menjadi efektif jika melibatkan 3 (tiga) aspek penting, yakni pengetahuan, perasaan, dan tindakan. Selain itu, untuk memahami bagaimana karakter anak, seseorang dapat melihatnya dari beberapa hal yang ada pada anak tersebut, antara lain apa yang ia tulis dan ia gambar, gerakan tubuhnya, gerakan tangannya, termasuk juga perubahan pada ekspresi wajahnya. Khusus pada pendidikan karakter pada sikap kejujuran yang menjadi poin penting untuk diimplementasikan pada diri anak, terdapat beberapa hal yang harus dilakukan oleh pengurus yakni 1). Menyakinkan pada diri anak bahwa kejujuran akan mendatangkan dan mampu membangun kepercayaan dari orang lain, 2). Melatih diri untuk berkata benar dan sesuai dengan fakta yang dilihatnya, dirasakan, dan dialami sendiri, dan 3). Tidak menjadikan kebohongan sebagai candaan dalam bergaul dengan sesama. 


\section{Daftar Pustaka}

Amin, M. (2017). Peran Guru Dalam Menanamkan Nilai Kejujuran Pada Lembaga Pendidikan. Tadbir : Jurnal Studi Manajemen Pendidikan, 1(1), 105. https://doi.org/10.29240/jsmp.v1i1.222

Arrahim, A. (2016). PENGEMBANGAN PENDIDIKAN KARAKTER MELALUI KANTIN KEJUJURAN. Jurnal Civic Hukum, 1(2), 49. https://doi.org/10.22219/jch.v1i2.10620

Emosda, E. (2011). Penanaman Nilai-nilai Kejujuran dalam Menyiapkan Karakter Bangsa. Innovatio, $X(1)$. https://scholar.google.co.id/citations?view_op=view_citation\&hl=en\& user=fbG2zcsAAAAJ\&alert_preview_top_rm $=2 \&$ citation_for_view $=\mathrm{fb}$ G2zcsAAAAJ:d1gkVwhDpl0C

Lena, L., Nelson, N., \& Siswanto, S. (2020). IMPLEMENTASI NILAI-NILAI KARAKTER MENURUT KEARIFAN LOKAL MASYARAKAT LEMBAK KECAMATAN BINDURIANG. PARAMUROBI: JURNAL PENDIDIKAN AGAMA ISLAM, 3(2), 43-63. https://doi.org/10.32699/paramurobi.v3i2.1388

Sawaludin, S., Muttaqin, Z., Sina, S., \& Saddam, S. (2019). Penerapan Model Pembelajaran Kreatif Produktif Untuk Meningkatkan Aktifitas Belajar Mahasiswa Melalui Lesson Study Di Program Studi Pendidikan Pancasila Dan Kewarganegaraan. INOPENDAS: Jurnal IImiah Kependidikan, 2(1). https://doi.org/10.24176/jino.v2i1.3443

Suriawati, S. (2016). NILAI-NILAI PENDIDIKAN KARAKTER DALAM NOVEL NEGERI DI UJUNG TANDUK KARYA TERE LIYE. Jurnal Pendidikan Dan Pembelajaran Khatulistiwa, 6(4). https://jurnal.untan.ac.id/index.php/jpdpb/article/view/19860

Zubaedi, Z. (2015). Desain pendidikan karakter: Konsepsi dan aplikasinya dalam lembaga pendidikan. Kencana.

Zuchdi, D. (Ed.). (2011). Pendidikan karakter dalam perspektif teori dan praktik (Cet. 1). UNY Press. 